\begin{tabular}{|l|c|c|c|c|}
\hline $\begin{array}{l}\text { Cuadernos de Investigación Geográfica } \\
\text { Geographical Research Letters }\end{array}$ & 2020 & N $^{\circ} 46(2)$ & pp. 497-519 & eISSN 1697-9540 \\
\hline
\end{tabular}

\title{
LITTLE ICE AGE, PALAEOFLOODS AND HUMAN ADAPTATION ON THE JARAMA RIVER (TAJO BASIN, SPAIN) FROM DOCUMENTARY PROXY DATA
}

\section{T. BULLÓN*}

Departamento de Geografía, Universidad Autónoma de Madrid, 28049 Madrid, Spain.

\begin{abstract}
This research assesses the close relationship between river history and human adaptation by combining the study of the migration of channels on the floodplain, the temporal distribution of floods, and human adaptation to the fluvial environment during the Little Ice Age (LIA) period on the Jarama River section situated between the mouths of two tributaries, the Henares and Manzanares. The methodology consists of the employment of abundant documentary records from the $14^{\text {th }}$ to $19^{\text {th }}$ centuries related to the response of society to hydrological dynamics within changing river patterns. The management and delimitation of land ownership, along with the readjustments and modifications therein, allow the inference of the changes that have taken place in the river throughout history. These changes include meander cut-offs, the abandonment of a channel fragment and aggradation in the alluvial plain, all of them located in different areas within the study area and with different historical timeframes. A relationship exists between changes in fluvial dynamics and the times of the greater abundance of floods. An initial change in the alluvial plain occurred in the Middle Ages as a result of the abandonment of the medieval channel and the creation of a new channel. The second change occurred between the $15^{\text {th }}$ and $17^{\text {th }}$ centuries and affected the properties on the right-hand bank of the river. Since the $18^{\text {th }}$ century, the abandonment of and reduction in meanders and the aggradation at the Manzanares-Jarama mouth have created a new alluvial plain of the river. The different phases of the LIA defined herein coincide with much of the palynological and dendrochronological research conducted in other areas of the southwestern fringe of Europe. From the historical point of view, critical changes appear to be associated with some LIA phases. Furthermore, the progressive transformation of communal lands into public or private property could be promoted by the intense floods recorded since the $15^{\text {th }}$ century. The Maunder and Dalton Minimums occurred together with an increase in the area assigned for agriculture on the alluvial plain; this land use type continued to grow during the $19^{\text {th }}$ and $20^{\text {th }}$ centuries.
\end{abstract}


Pequeña Edad del Hielo, paleoavenidas y adaptación humana en el río Jarama (Cuenca del Tajo, España) a partir de datos documentales

RESUMEN. Esta investigación estudia la estrecha relación que existe entre la historia del río Jarama y la adaptación humana a ella mediante el análisis simultáneo de la migración de los canales en la llanura de inundación, la distribución temporal de las avenidas y la adaptación humana al territorio fluvial durante la Pequeña Edad del Hielo (PEH) en el tramo bajo del río Jarama situado entre los dos tributarios Henares y Manzanares. El método de trabajo consiste en utilizar la abundante documentación histórica que existe sobre los siglos XIV al XIX, referente a la respuesta de la sociedad humana a la dinámica hidrológica, en un contexto de unos cambios fluviales casi constantes. La delimitación y gestión de la propiedad de la tierra, así como las modificaciones que se producen en ella sirven para deducir los cambios que han ocurrido en el río a lo largo de la historia. Estos cambios consisten en migración y segmentación de meandros, abandono de un fragmento de canal y agradación de la llanura aluvial, todos ellos localizados en diferentes áreas de la zona de estudio, en diferentes franjas temporales. Existe una relación entre los cambios de en la dinámica fluvial y los momentos de mayor abundancia de avenidas. Un cambio inicial tuvo lugar en la Edad Media y produjo el abandono de un antiguo canal y la creación de otro nuevo. El segundo cambio ocurre entre los siglos XV al XVII y afecta a las propiedades situadas en la orilla derecha del río. Finalmente, en el siglo XVIII el abandono o reducción de algunos meandros y la agradación ocurrida en el área de confluencia Manzanares-Jarama crean un nuevo tipo de llanura aluvial del río.

El rio Jarama conserva la señal de las oscilaciones climáticas históricas que han ocurrido. Las diferentes fases de la PEH definidas coinciden con la mayor parte de los resultados de las investigaciones palinológicas y dendroclimáticas obtenidos en otras áreas situadas en el borde suroccidental del continente europeo. Desde el punto de vista histórico las fases de la PEH están asociadas a cambios importantes. Además la progresiva transformación de las tierras comunales en tierras de propiedad pública o privada pudo haber sido impulsada por las intensas avenidas que empiezan a ocurrir a partir del siglo XV. Los mínimos de Maunder y Dalton ocurren en coincidencia con el incremento en la llanura aluvial de la agricultura cerealista, que se hace extensiva durante los siglos XIX y XX.

Key words: Fluvial evolution, Little Ice Age, documentary proxy data, Jarama basin, central Spain.

Palabras clave: evolución fluvial, Pequeña Edad del Hielo, datos históricos documentales, Cuenca del Jarama, España central.

Received: 31 May 2019

Accepted: 2 January 2020

*Corresponding author: Teresa Bullón, Departamento de Geografía, Universidad Autónoma de Madrid, Cantoblanco, 28049 Madrid, Spain. E-mail address: teresa.bullon@uam.es 


\section{Introduction}

The gradual increase in water use and the growing urban expansion on floodplains endangers the quality of the water and of the fluvial ecosystems; there is therefore a need to provide additional in-depth knowledge on the shapes and dynamics of rivers to establish scientific criteria for the conservation of the resources and services associated with these fluvial areas (Ollero and Elso, 2006).

The management of floodplains depends on the definition of fluvial territory and flood risk zones and is based on the knowledge of the intensity and temporal sequence of floods at the present time and in the historical past in their relationship with climate. In line with this approach, it is of particular interest to extract information from the narrow time span existing between the contemporary instrumental period and the beginning of human descriptions about fluvial events, which can be accessed by means of the analysis of historical documentation.

Research on flood episodes in the recent pre-instrumental past based on written or graphic documents is closely associated with palaeoclimatic reconstructions; it makes use of specific methods to gather and assess the information (Brázdil et al., 2010; Camuffo et $a l ., 2010$ ), and the results have often served to establish hypotheses referring to present and future climate change and evolution.

\subsection{Hypothesis and objectives}

The hypothesis of this work is that the documents referring to land uses and management on an alluvial plain are capable of providing highly accurate information on the morphodynamics of the river. Specifically, this hypothesis postulates that it is possible to establish a connection between the migration of the channels on the floodplain, the temporality of the floods and the human occupation of the fluvial territory. Thus, evidence is expected to be obtained to facilitate comparison with analyses and chronologies obtained through other scientific procedures within the time span considered.

The objectives proposed involve (i) establishing the relative spatial and chronological distribution of fluvial morphologies with the use of the data collected and (ii) determining the palaeoclimatic implications of the temporal sequence of floods by means of the interpretation and quantification of the qualitative data and statistical treatments.

\subsection{State of the art and contextualization}

Previous scientific contributions related to the present research show two different approaches. First, there are palaeoclimatic and palaeohydrological reconstructions, which are useful for deducing the temporal variability in precipitation and floods during the last 500 years in Europe (Brázdil et al., 2006; Glaser et al., 2010) and Spain (Barriendos and Coeur, 2004; Barriendos and Rodrigo, 2006; Rodrigo and Barriendos, 2008). A complete study of floods in Cataluña from the $14^{\text {th }}$ century was conducted by Llasat $e t$ al., 2005, which is also associated with the Maldás wet oscillation, situated within the Dalton phase of the LIA (Barriendos and Llasat, 2003). Flood intensities associated with 
the wet phases of the LIA in different Spanish areas were studied by Rodrigo et al., 2000 and Rodrigo et al., 2018 in Andalucía and by Benito et al., 2003; Uribelarrea et al.,2003; Uribelarrea et al., 2004 and Bullón, 2011 in the Tagus and Jarama-Tagus River basins.

Second, geomorphological and sedimentary studies are interesting because they demonstrate the essential role of the Jarama valley in the reconstruction of the Quaternary past in Central Spain. These studies analysed the sequences of steep fill and cut terraces and of piled up alluvial deposits in the valley bottom, with the aim of defining absolute and relative sedimentary dates ranging from the Matuyana-Brunhes reversal (Panera et al., 2011; Pérez González et al., 2012), to the recent Holocene (Wolf et al., 2013). The sedimentary series of the Jarama valley also present numerous archaeological sites, and in many cases, archaeological and sedimentary research has advanced simultaneously, both in Palaeolithic (Santonja et al., 1979 and 1980; Panera et al., 2011) and Neolithic deposits (Martin Bañón, 2007). Settlement occurred profusely in historical times because many Roman and Visigoth remains can be found.

In this context, the present research consists of a study of transformations and changes in fluvial dynamics between the $14^{\text {th }}$ and $19^{\text {th }}$ centuries from documentary proxy data. It makes use of written documents as proxies to observe the relationship between the river and human history and to acquire some types of information that could not otherwise be detected separately either by the historical or the earth sciences.

\section{Study area}

The Jarama hydrographic basin is situated on the central southern plateau (Meseta) of Spain and comprises most of the southern face of the Guadarrama, Somosierra and Ayllón Mountains (summit at $2428 \mathrm{~m}$ ) belonging to the Central Range, as well as the piedmonts between this range and the Tajo sedimentary basin. Waters from the mountains constitute the largest part of the discharge of the river. The Jarama basin has an area of $11,597 \mathrm{~km}^{2}$ at the 3052 gauging station, situated at the north fringe of the study area (https://sig.mapama.gob.es/redes-seguimiento/). According to data provided by the abovementioned gauging station, the mean annual discharge is $25.741 \mathrm{~m}^{3} / \mathrm{sec}$, and the minimum is $5.7 \mathrm{~m}^{3} / \mathrm{sec}$, with maximum instantaneous discharges of $1237.50 \mathrm{~m}^{3} / \mathrm{sec}$, similar to those that occurred in January 1970. High waters occur during the mountain snow-melting period, with a maximum in February, which is 8-fold higher than the low waters in August. Systematic discharge is also associated with a semiarid rainfall regime of the Mediterranean type, with a maximum in October-December and a minimum in August. Annual precipitation exhibited an average of $432 \mathrm{~mm}$ at the Agencia Estatal de Meteorología (National Meteorological Agency) (AEMET) meteorological station number 3195 Madrid-Retiro, although during 48 months from 1920 to 2011, precipitation exceeded $100 \mathrm{~mm}, 60 \%$ of which was from October to December. (https://opendata. aemet.es/centrodedescargas/productosAEMET).

The study area has an average altitude of $590 \mathrm{~m}$ and lies in the low Jarama valley segment located south of the Henares River mouth and continues until the Manzanares River mouth area (Fig. 1), and the average channel slope is $0.133 \%$ (Vizcaíno et al., 
2003). The area consists mainly of a fluvial landscape containing Páramo landforms made up of sedimentary massive gypsum rocks from the Tertiary age and alluvial plains established on Pleistocene and Holocene Quaternary sediments.

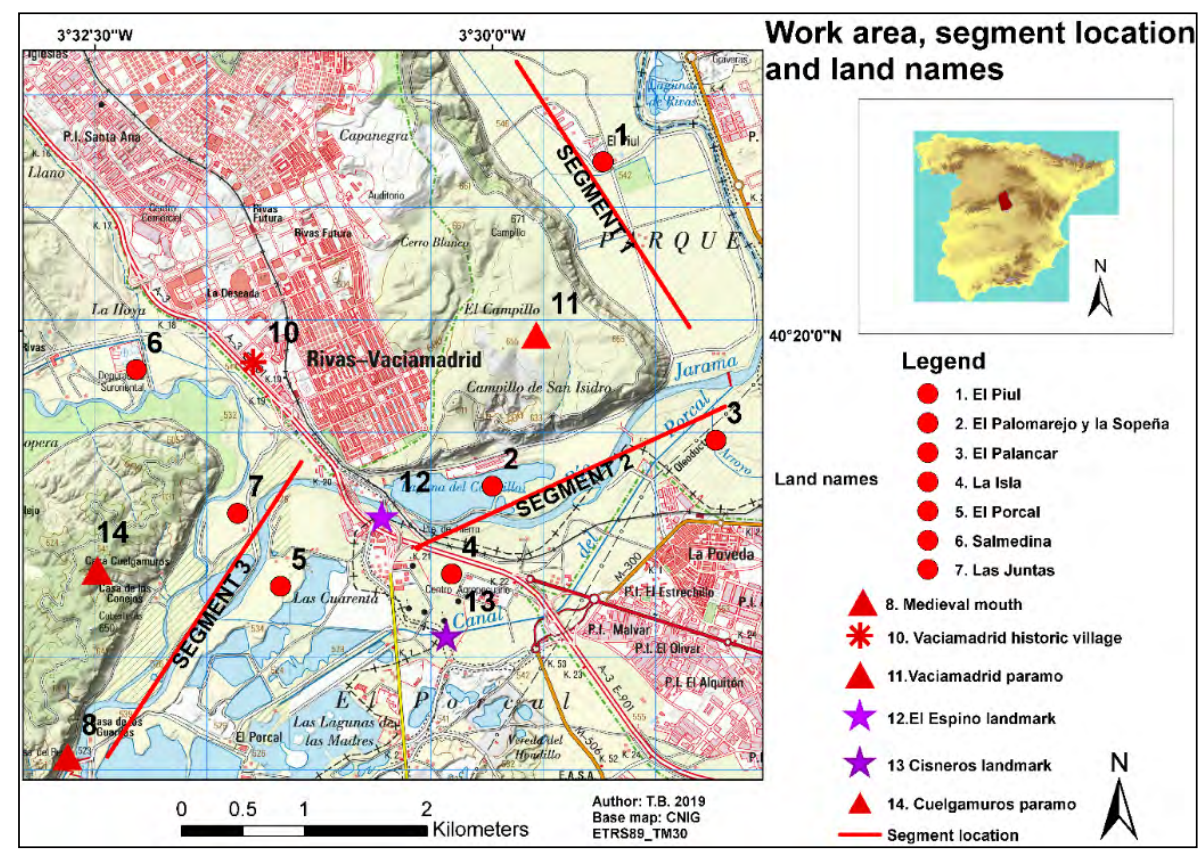

Figure 1. Study area, location of the three segment areas of the river used in this work and historic local geographic names.

The Quaternary sediments are situated on evaporitic series approximately $100 \mathrm{~m}$ thick, comprising massive gypsums and gypsum marls of Tertiary chronology and whose intense karstification creates local sinkholes and collapses. Likewise, there are subsidence processes on the alluvial plain of neotectonic origin, which together with karstification are responsible for the piling up of Quaternary alluvial sediments in the valley bottom. (Silva et al., 1998; Silva 2003; Pérez González et al., 2012; Wolf and Faust, 2016).

Land uses in the temporal section analysed consist mainly of semi-active alluvial terrain subject to frequent floods devoted to pastures, hunting, forest cutting and fishing. Riparian species such as poplar, ash or tamarisk constitute elements of the landscape that serve to identify the layout of the old water courses and that of the rectified or abandoned meanders. The territory was divided into farmlands belonging to the municipalities of Madrid and Arganda, to the Archbisopric of Toledo and to the Spanish royal family (the latter gave some lands to the Monastery of San Lorenzo del Escorial).

The most significant territorial occupation began in the Andalusí period, between the $8^{\text {th }}$ and $9^{\text {th }}$ centuries (Sánchez, 1962; Malalana, 1995; Fernández Montes, 
2004). From the $12^{\text {th }}$ and $13^{\text {th }}$ centuries, the land was widely exploited, with land management being explicitly defined (Millares and Artiles, 1932). In the following centuries, private or public land ownership coexisted with communities of citizens under a communal system. As from the modern age, much of the communal land became municipal property or was absorbed by the large landowners as the riverside towns gained greater importance and the territory became more distant from the Christian-Muslim conflicts (Madrazo et al., 1991, Hernando Ortego, 2003). The $18^{\text {th }}$ century exhibited a tendency towards an increase in cereal crops to the detriment of forestry and livestock farming (Arroyo, 2002; Fernández et al., 2016). Regulations during the desamortización period (expropriation of church and council lands by the national state) in the $19^{\text {th }}$ century favoured an increase in croplands, which reached its height in the second half of the $20^{\text {th }}$ century (Vizcaíno et al., 2003; Molina and Berrocal, 2013).

\section{Methodology}

\subsection{Data processing and evaluation about the interaction of human society and the river}

The method consists of appraising each of the information entries found, jointly considering the normative value of the texts, their purpose, the reason why the author provided the description of the river and the date thereof, in accordance with the procedures employed in similar studies. The information compiled is from files on lawsuits, rulings and claims associated with the management of the alluvial plain. The descriptions of boundaries provide details, although this is not the main aim of the document, of the methods used to control the river dynamics to maintain the limits of ownership and of the habitual exploitation of resources.

Each datum collected is identified by the year it refers to because, although documents are usually dated by year, month and day, the events described therein could have happened on other dates. The type of datum obtained can be explicit, objectively describing a flood and its associated circulation of water and sediments, or implicit, making no direct reference to the event that caused damage. These events include the failure and deterioration of bridges, barges, dams and manmade channelizations. We evaluated the severity of the events by identifying the places where they occurred and by the geomorphological interpretations of the events with the help of local place names and historical aerial photographs.

\subsection{Documentary collections}

The data employed were extracted from original documents coetaneous to the events. The archives and sections containing these documents are indicated in Table 1. Transcribed and published documents were also employed, such as the Fuero de Madrid (Sánchez et al. 1962) and Libro Acuerdos del Concejo Madrileño, volumes 1 to 4: Millares and Artiles (1932); Gómez (1970); Rubio (1979); Rubio et al. (1982), and for 1561-1598 Alvar et al. (2005), see also Table 1. 
Table 1. Archives and sections consulted.

\begin{tabular}{|l|c|l|l|l|}
\hline Archive name & Acronym & \multicolumn{1}{|c|}{ Section } & \multicolumn{1}{c|}{ Range } & \multicolumn{1}{|c|}{ English name } \\
\hline $\begin{array}{l}\text { Archivo de Villa de } \\
\text { Madrid }\end{array}$ & AVM & $\begin{array}{l}\text { 1 Corregimiento } \\
\text { 3 Secretaría }\end{array}$ & $\begin{array}{l}\text { Local and } \\
\text { regional }\end{array}$ & $\begin{array}{l}\text { Madrid Town Archive } \\
\text { 1 Council } \\
\text { 3 Secretary }\end{array}$ \\
\hline $\begin{array}{l}\text { Archivo Municipal de } \\
\text { Arganda }\end{array}$ & AMA & -- & $\begin{array}{l}\text { Local and } \\
\text { regional }\end{array}$ & Arganda Town Archive \\
\hline $\begin{array}{l}\text { Archivo del Real } \\
\text { Monasterio de San } \\
\text { Lorenzo del Escorial }\end{array}$ & ARMSLE & $\begin{array}{l}\text { AC. Actas capitulares } \\
\text { LC. Libros de cuentas }\end{array}$ & $\begin{array}{l}\text { Escorial Royal Monastery Archive } \\
\text { AC. Capitulary Minutes } \\
\text { LC. Account books }\end{array}$ \\
\hline $\begin{array}{l}\text { Archivo General de } \\
\text { Simancas }\end{array}$ & AGS & $\begin{array}{l}\text { CyS. Casas y sitios Reales } \\
\text { PR.Patronato Real } \\
\text { RGS. Registro General del } \\
\text { Sello } \\
\text { MPD. Mapas, planos y dibujos }\end{array}$ & $\begin{array}{l}\text { General } \\
\text { CyS. Royal houses and sites } \\
\text { PR.Royal Patronage } \\
\text { RGS. General Stamps Register } \\
\text { MPD. Maps, plans and drawings }\end{array}$ \\
\hline $\begin{array}{l}\text { Archivo de la Real } \\
\text { Chancillería de Valladolid }\end{array}$ & ACHV & Registro de ejecutorias & General & $\begin{array}{l}\text { Valladolid Royal Chancellery Archive. } \\
\text { Executory register }\end{array}$ \\
\hline $\begin{array}{l}\text { Archivo General de } \\
\text { Palacio }\end{array}$ & AGP & $\begin{array}{l}\text { Administraciones Patrimoni- } \\
\text { ales. Aranjuez }\end{array}$ & General & $\begin{array}{l}\text { General Royal Palace Archive } \\
\text { Heritage administration. Aranjuez }\end{array}$ \\
\hline
\end{tabular}

Digital access to many documents was provided by the Portal de Archivos Españoles (Spanish Archives Portal) PARES http://pares.mcu.es/ and by the Archivo Digital del Municipio de Arganda (Arganda Town Digital Archive) http://archivo.ayto-arganda.es/ ElArchivo/Fondos.aspx

\subsection{Cartographic analysis}

The cartographic analysis consisted of comparing the different layouts of the main channels of the river Jarama on different maps based on the georeferencing of all of these, providing they presented sufficient cartographic quality. The historic and contemporaneous maps used are shown in Table 2. The basis of the georeferencing is a layer of hillshade created by the author with the use of the digital terrain model (DTM) with an accuracy of 5 metres. Topographic maps, geological maps and DTMs have the following identification: 559 Madrid; 560 Alcalá de Henares; 582 Getafe and 589 Arganda del Rey.

Table 2. Historic maps used.

\begin{tabular}{|c|c|c|}
\hline Name & Map signature & Web \\
\hline \multirow{2}{*}{$\begin{array}{l}\text { Archivo general } \\
\text { de Simancas, AGS }\end{array}$} & MPD 22-049 & http://www.mcu.es/ccbae/es/consulta/registro.cmd?id=181048) \\
\hline & MPD 71,031 & $\begin{array}{l}\text { http://www.mcu.es/ccbae/es/catalogo_imagenes/grupo.cmd?interno=S\&- } \\
\text { path=11104 }\end{array}$ \\
\hline $\begin{array}{l}\text { Biblioteca Nacio- } \\
\text { nal de España }\end{array}$ & $\begin{array}{l}\text { BN (CBiblioteca } \\
\text { Nacional Mr 43-12 }\end{array}$ & No digital access \\
\hline $\begin{array}{l}\text { Archivo General } \\
\text { de Palacio }\end{array}$ & AP, map 1818 & No digital access \\
\hline $\begin{array}{l}\text { Centro Nacional } \\
\text { de Información } \\
\text { Geográfica, CNIG }\end{array}$ & $\begin{array}{l}\text { Digital Terrain Model } \\
\text { Topographic maps } \\
\text { (form first edition) } \\
\text { Aerial photographs } \\
\text { (1946 and 1957) }\end{array}$ & http://centrodedescargas.cnig.es/CentroDescargas/buscador.do \\
\hline $\begin{array}{l}\text { Instituto Geoló- } \\
\text { gico y Minero, } \\
\text { IGME }\end{array}$ & $\begin{array}{l}\text { Serie Magna 1: } \\
\quad 50,000\end{array}$ & http://info.igme.es/cartografiadigital/geologica/Magna50.aspx. \\
\hline
\end{tabular}


The method of georeferencing consisted of defining at least three control points between the orthorectified historical aerial photographs and the historical map by means of a $1^{\text {st }}$ order polynomial transformation (Affine), ensuring that the residuals $\mathrm{X}$ and $\mathrm{Y}$ were as low as possible. The control points were situated in fixed elements of the terrain, such as topographic features, buildings or crossroads. The cartography of a georeferenced element was validated when the evidence of it could be observed in the aerial photography in such a way that the final mapping of this element resulted from the combination of photointerpretation and georeferencing.

The establishment of the mapped polygons and lines followed a similar procedure since they result from the localisation in the aerial photographs of geomorphological features that could be associated with documentary information. In this sense, the cartography created constitutes a spatial and synthetic illustration of the documentary information compiled in which each mapped feature has evidence in the terrain and in the documentary analysis. The dates assigned refer to the date on the documents employed. The initial editions of the topographic maps of the study area provide highly valuable complementary information because they indicate the positions of the river that differ both from previous times and from the present.

\subsection{Temporal sequence of floods}

The damage caused by floods, such as the destruction of structures built on the river or its boundaries, erosion or accumulation of sediments on the banks, and flooding of productive lands, was employed to establish a chronological sequence of the number of flood-related events. The resulting data series contains the number of events causing damage each year in different places along the riverbank.

The statistical method followed to account for the performance of this time series by the means of a temporal analysis model that consisted of separating in the original variable, one cycle-tendency theoretical series, which expresses the long-term behaviour of the data and filters them in relation to two other series of residuals representing the short-term movements or random movements, as well those extracted from the original series. The most suitable model for explaining the data was chosen according to the values obtained by the statistics: stationary R-squared (SRS), mean absolute error (MAE) and the Bayesian information criterion (BIC), where SRS is the proportion of variation in the dependent variable explained by the regression model, and the BIC is the likelihood function that measures the efficiency of the parameterised model in terms of predicting the data. The independence of the residuals is measured by means of the $\mathrm{Q}$ of the Ljung-Box statistic. The final definition of the groups of years presenting a greater or lesser abundance of damage caused by floods was obtained by means of the normalised cycle-tendency time series. 


\section{Results of the analysis}

\subsection{Fluvial activity in the alluvial floodplain}

To better explain the results, the alluvial plain was divided into three segments (Fig. 1). Segment 1 is situated in the northernmost position, has a general NNW-SSE direction and exhibits meandering channels. Segments 2 and 3 follow WSW-ENE and SSWNNE directions, respectively and have decreasing sinuosity, while the slope increases in segment 2.

The three effects of fluvial dynamics detected in documents are meander cut-off, channel abandonment of a segment of the main channel, and aggradation of the alluvial plain.

\subsubsection{Meander cut-off}

Changes in the shape and channels of the river are recurrent in the documents consulted, affecting primarily segment 1 between the $14^{\text {th }}$ and $15^{\text {th }}$ centuries, segment 1 was full of quickly changing meanders (Fig. 2), (AGS PR, 33-35 and 33-37; AVM 3-9-16 and 3-9-18; RMSLE AC 27-32), (Table 3). There is ample information on this, indicating that many properties belonging to different owners were often fragmented or isolated because of these changes. These were so extreme that the properties had to be reassigned and redistributed in accordance with the geometry of the river channel.

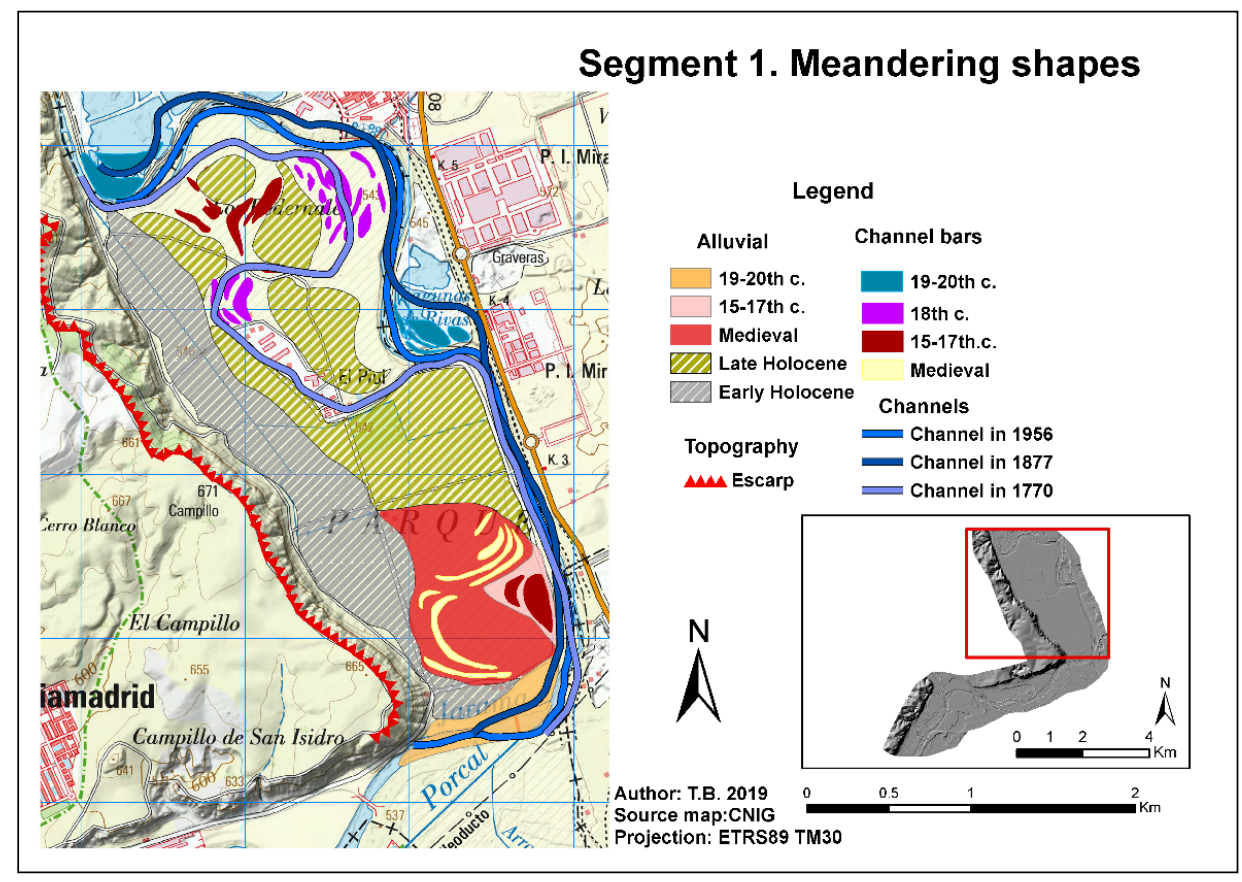

Figure 2. Identification of channels and bars with different historic dates in segment 1. 
Table 3. Documents used to analyse the fluvial activity in the alluvial plain. See Table 1 for the archive and section acronym identification.

\begin{tabular}{|l|c|c|l|c|}
\hline \multicolumn{1}{|c|}{ Archive } & $\begin{array}{c}\text { Document } \\
\text { signature }\end{array}$ & Date & \multicolumn{1}{|c|}{ Main contain } & Section \\
\hline \multirow{2}{*}{ AVM } & $3-99-16$ & 1300 & $\begin{array}{l}\text { Swap contract Madrid Council / Toledo Archbishopric. } \text { El } \\
\text { Piul }\end{array}$ & \\
\cline { 2 - 4 } & $3-99-18$ & 1536 & $\begin{array}{l}\text { Lawsuit among Madrid Council / Toledo Archbishopric. } \text { El } \\
\text { Piul }\end{array}$ & \multirow{2}{*}{$\begin{array}{c}\text { Meander } \\
\text { cut-off }\end{array}$} \\
\cline { 2 - 4 } LACM & VOL 1 & $\begin{array}{c}10 / 1482 \text { and } \\
12 / 1484\end{array}$ & Stockades and landmarks in El Piul & \\
\hline RMSLE-AC & $27,28,32$ & 1572 & Land ownership. El Piul & \\
\hline AGS PR & $33-35$ & 1578 & Land transfer El Piul-Palomarejo & \\
\hline AGS PR & $33-37$ & 1580 & Swap contract Madrid C.-Toledo A.-Royal Family & \\
\hline AGS SyCR & $147 / 189$ & 1579 & Old channels property in El Piul & \\
\hline
\end{tabular}

\begin{tabular}{|c|c|c|c|c|}
\hline \multirow{7}{*}{ AVM } & $2-158-11$ & 1327 & Abandoned channel disputed between Madrid-Arganda & \multirow{12}{*}{$\begin{array}{c}\text { Channel } \\
\text { abandonment }\end{array}$} \\
\hline & $3-16,23$ & 1788 & Flooding in Rincón de los Ciervos area & \\
\hline & $3-16-32$ & $1584-88$ & Municipal boundaries Madrid-Arganda & \\
\hline & $3-41-29$ & 1585 & Municipal boundaries Madrid-Arganda & \\
\hline & 3-91-14 & 1495 & Trial on Rincón de los Ciervos & \\
\hline & $3-100-3$ & 1663 & Abandoned channel disputed between Madrid-Arganda & \\
\hline & $3-160-7$ & 1770 & Abandoned channel disputed between Madrid-Arganda & \\
\hline LACM & Vol 1 & $\begin{array}{c}03-05 / 1481 ; 01 \\
\text { to } 0 / 3 / 1486 ; 03 \text { to } \\
07 / 1489\end{array}$ & $\begin{array}{l}\text { Channel changes in El Porcal and La Sopeña between Ma- } \\
\text { drid and Arganda }\end{array}$ & \\
\hline \multirow{2}{*}{ AMA } & DD0000270003 & 1591 & $\begin{array}{l}\text { Legal proceedings about the abandoned channel Madrid-Ar- } \\
\text { ganda }\end{array}$ & \\
\hline & $\begin{array}{l}013700110000 \text {, } \\
\text { parts a, b and c }\end{array}$ & $1607-32$ & Abandoned channel disputed between Madrid-Arganda & \\
\hline AGS SyCR & $147 / 189$ & 1579 & Trial on land rearrangements in the Jarama Alluvial plain & \\
\hline $\mathrm{ACHV}, \mathrm{RE}$ & 1736,33 & 1591 & $\begin{array}{l}\text { Legal proceedings about the abandoned channel Madrid-Ar- } \\
\text { ganda }\end{array}$ & \\
\hline
\end{tabular}

\begin{tabular}{|c|c|c|c|c|}
\hline \multirow{5}{*}{ AVM } & $3-14-42$ & 1683 & New sediment island at the Manzanares mouth & \multirow{6}{*}{ Aggradation } \\
\hline & $3-16-23$ & 1788 & Continuous flooding downstream the Manzanares mouth & \\
\hline & $3-160-3$ & 1789 & New alluvial plain downstream the Manzanares mouth & \\
\hline & $3-160-9$ & 1793 & New land demarcations between Madrid and Vaciamadrid & \\
\hline & $3-169-24$ & 1806 & Dossier on new lands in Vaciamadrid & \\
\hline ACHV-RE & 3698.0015 & 1799 & Executory of the lawsuit on Vaciamadrid & \\
\hline
\end{tabular}

The historical reconstruction of the river during the $18^{\text {th }}$ and $19^{\text {th }}$ centuries was made in the area connecting segments 1 and 2 with the help of the 1770 map, the digital terrain model and aerial photos from 1946 and 1956. On the map from 1770 (Fig. 3, 2a), there was a large meander (El Palancar in Fig. 4), which would later be abandoned in the $19^{\text {th }}$ century. The most salient remaining feature of the meander is a large oxbow-type residual lake that has remained in place until recent times. The 1770 map also includes another wide meander in the central part of sector 1, though its curvature progressively disappears from maps edited in the $19^{\text {th }}$ and $20^{\text {th }}$ centuries. 


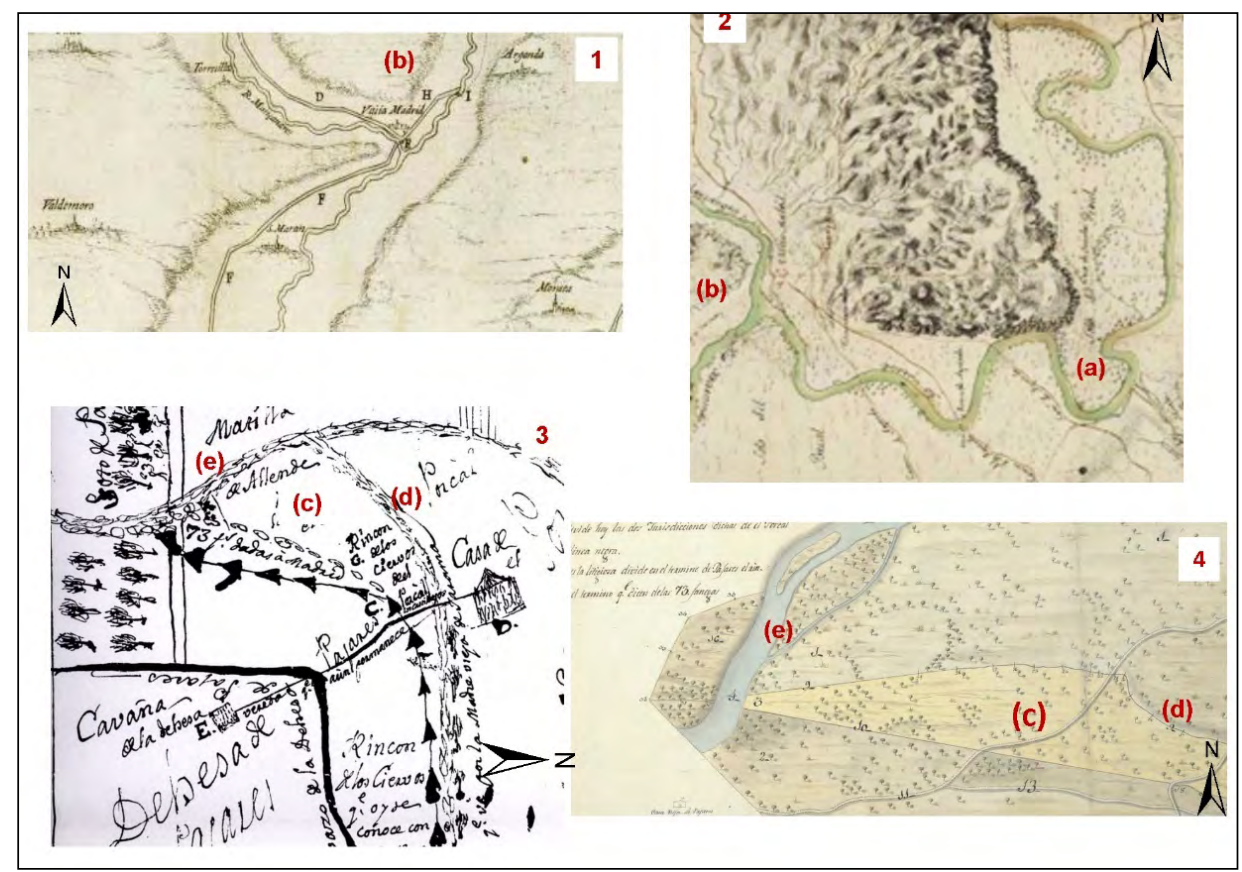

Figure 3. Identification of unique fluvial elements on historical maps and drawings (fragments):

1 Confluence of the Manzanares-Jarama Rivers from 1668 (AGS, MPD 71,031). 2 Map from

1777 (AGS-MPD 22-049). 3 Drawing of the Monastery of San Lorenzo del Escorial (AP, 1818). 4 Map by E. Biescas 1781 (BN @Biblioteca Nacional Mr 43-12). $a=$ meander between segments 1 and 2; $b=$ Jarama-Manzanares confluence; $c=$ Rincón de los Ciervos; $d=$ abandoned channel of the Jarama River; $e=$ Current channel of the river.

\subsubsection{Channel abandonment and the definition of new ones}

In segment 2, the legal boundaries between the three land properties situated on the left bank of the Jarama River, soto del Porcal, soto de la Isla and soto de Pajares (see Fig. 1 for local names), were settled along an old river channel presenting a clearly meandering path. This channel ran southwards until the Cisneros landmark (Fig. 1) (AVM 3-16-32 and 3-41-29), and from there, it turned southwest, reaching the Jarama River downstream from the $17^{\text {th }}$ century confluence of the Jarama and Manzanares Rivers in Vaciamadrid.

The profile of the abandoned channel fragment is evident both in historical and in contemporary maps as well as in aerial photos taken in the 20 $20^{\text {th }}$ century (Figs. 3 and 5). Although the channel fragment has not been interpreted or dated, it is represented in 1985 by Arche (2009) with a meandering layout that disappears in the Holocene floodplain. In other geomorphological maps (IGME, Magna $n^{\circ}$ 583; Silva, 2003; Panera et al., 2011), only the first part of this old channel is represented, indicating that it previously flowed northward, developing an alluvial fan at the confluence with the main river. 
The first part of the old abandoned channel was never disputed because the boundary is fixed in the middle of the channel and was of common use among the neighbouring owners, Madrid and Arganda councils, for livestock farming and forestry. The second segment of this channel (Rincón de los Ciervos) has been the object of frequent territorial fights since the early $15^{\text {th }}$ century and continued to be disputed until well into the $19^{\text {th }}$ century.

The historical data gathered indicate that the Jarama River could have flowed through this old channel up to the early 15 th century, (AVM, 3-91-14; LACM Vol 11481 to 1486; Sánchez et al., 1962). In addition, there are numerous references to this section of the river in several historical maps (AVM 0,51-31-32; BN CBiblioteca Nacional Mr 43-12; AP, 1818) (Figs. 3, 4, and 5; Table 3).

The alternative new channel of the river, active since the $15^{\text {th }}$ century, was shorter and straighter, running alongside the páramo of Vaciamadrid and joining the Manzanares River $4 \mathrm{~km}$ upstream from the abandoned channel. This new channel was braided in shape and associated with a significant set of fluvial bars, about which abundant documentation exists between the $15^{\text {th }}$ and $17^{\text {th }}$ centuries and that were located on the right bank of the new channel in the 1946 and 1957 aerial photos (Fig. 4). By contrast, the lands on the left bank of the river have essentially no changes. Cartographies generated from the $18^{\text {th }}$ century indicate that this channel acquired a migrating trend, moving progressively to a more southern position and acquiring a meandering layout (Fig. 4).

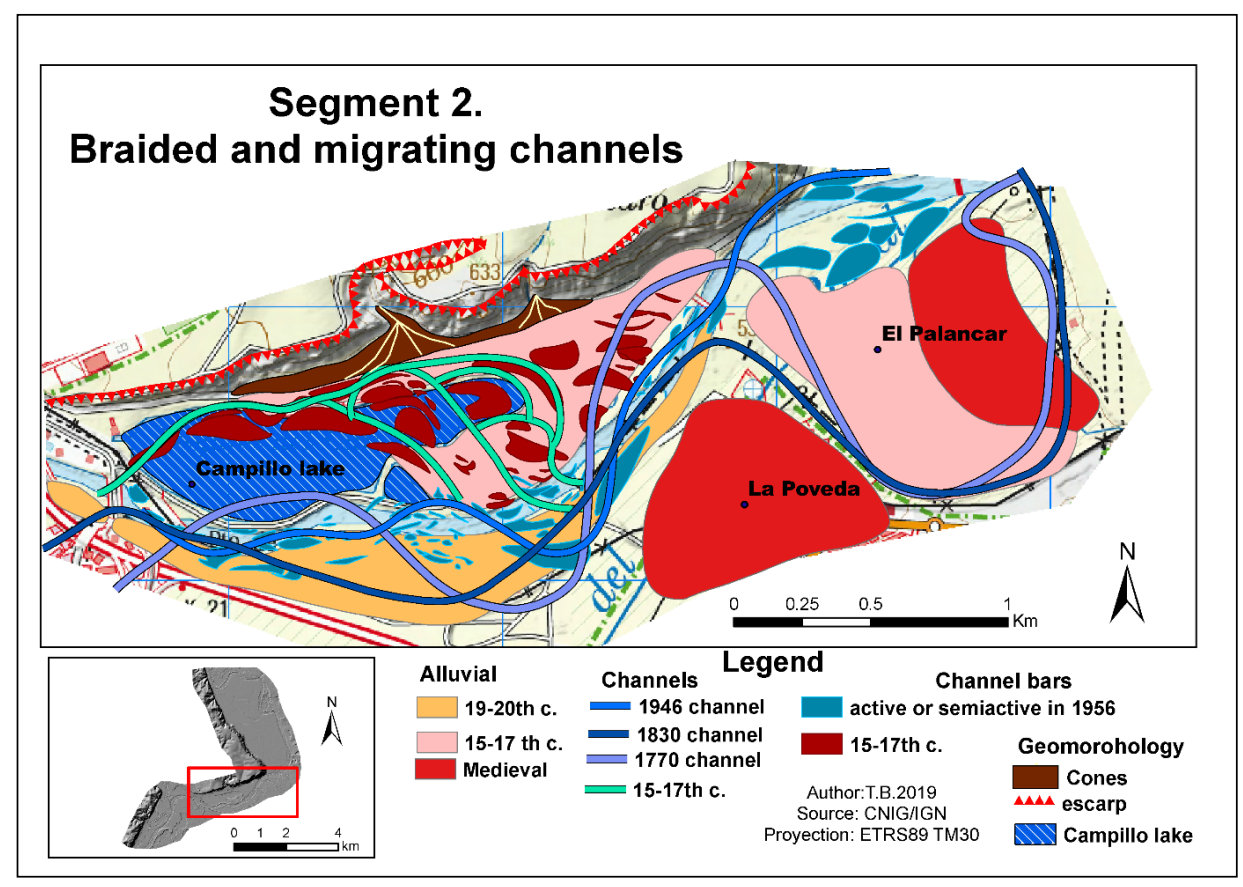

Figure 4. Channels and bars from different dates in segment 2. 
The human consequences of the changes caused by the new channel include, among others, the abandonment and ruin of properties located on its right bank, the constant need for administrative intervention to redefine the boundaries between properties that were continuously invaded or damaged by the river and the growing uncertainty and personal risk of crossing the new segment of the Jarama River by the bridges and barges historically used.

\subsubsection{Aggradation in the confluence of the Jarama and Manzanares Rivers}

The tendency for sedimentation at the confluence of the Manzanares and Jarama Rivers was first described in documents dating back to the $17^{\text {th }}$ century, indicating that this segment previously exhibited abundant sedimentation and many temporary channels with rapid flow rates (AVM, 3-16-23). The islands of sediments accumulating directly below the main confluence (AVM, 3-14-42) were frequent. Somewhat further south, numerous reports also provide information about islands of sand forming, and despite the projects intended to eliminate them, these islands finally joined together to form a continuous alluvial plain (AVM, 3-16-23 and 3-160-3). This trend continued over the following centuries until achieving the complete remodelling of the alluvial plain. The most notable consequence of all this has been the progressive and staged southern migration of the point where the two rivers meet. This can be seen in the aerial photos and topographical maps (Fig. 5).

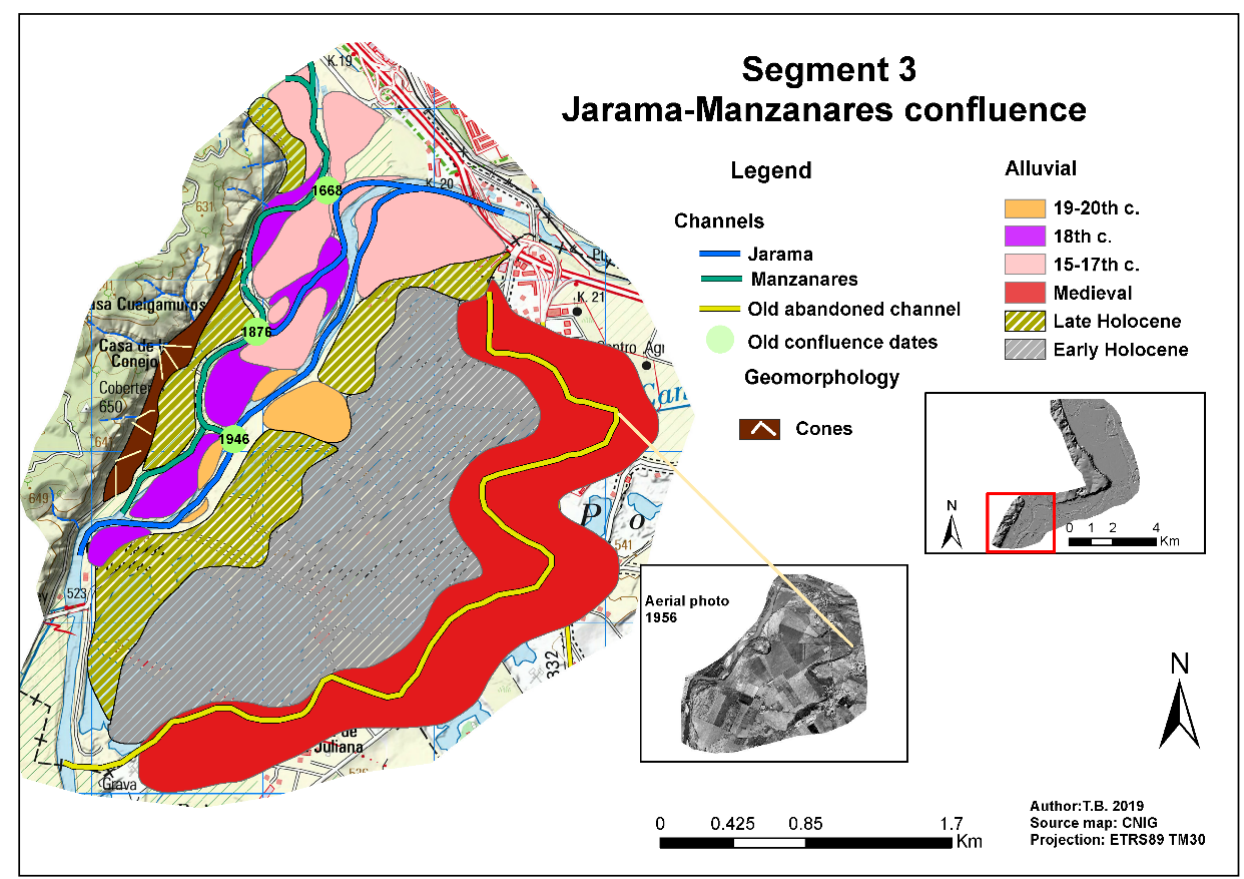

Figure 5. Recent migration of the river in the Manzanares-Jarama confluence in segment 3. 
The consequences on land ownership of the remodelling of the alluvial plain were significant, as its reconfiguration exposed new areas that were legally considered abandoned land and assigned to new landowners (AVM, 3-160-9 and 3-169-24; ACHVRE 3698.0015) (Table 3).

\subsection{Temporal sequence of flood damage}

The chronological sequence obtained classifies the data collected for each year and covers 380 years (Table 4). Its coefficient of variation is 1.3 and presents no tendency. Once the statistics summarising the different models tested had been compared, the best statistic was Holt's double smoothing exponential, which substitutes each item of the series with the weighted average of the previous observations, considering that their weighted average decreases as these move away in time. This temporal model presents a high RSR (0.80), with a relatively low MAE (0.79) and BIC (0.18). Additionally, the $\mathrm{Q}$ of the Ljung-Box statistic has significance $>0.05$, which indicates the random distribution of residuals.

Table 4. Documents used for the temporal sequence of flood assessment.

\begin{tabular}{|c|c|c|c|c|}
\hline Archive & Section & Range of years & $\begin{array}{c}\text { Total } \\
\text { events }\end{array}$ & $\%$ events \\
\hline \multirow{2}{*}{ AVM } & Secretary. Book 49 (bridges) & $1339-1820$ & \multirow{2}{*}{157} & \multirow{2}{*}{53.8} \\
\hline & Secretary. Book 67 (barges) & $1517-1820$ & & \\
\hline \multirow{2}{*}{ LACM } & Volumes 1-4 & $1460-1515$ & \multirow{2}{*}{55} & \multirow{2}{*}{18.8} \\
\hline & Alvar et al. (2005) & $1561-1598$ & & \\
\hline AMA & General & $1498-1811$ & 11 & 3.8 \\
\hline \multirow{2}{*}{ RMSLE } & Capitulary minutes & $1562-1792$ & \multirow{2}{*}{25} & \multirow{2}{*}{8.6} \\
\hline & Account books & $1770-1802$ & & \\
\hline AGS & Royal sites and houses & $1550-1600$ & 41 & 14.0 \\
\hline Other Archives & Disperse and punctual items & $1460-1820$ & 3 & 1 \\
\hline
\end{tabular}

The normalised series (Fig. 6, Table 5) reveals four distinguishable periods exhibiting a high abundance of floods situated 0.5 points above the normal value. The first of these periods, between 1481 and 1520, exhibit flood duration greater than in any of the subsequent periods. The second group, from 1594 to 1610 , is less significant than the first group and comprises a smaller number of years. The third group, between 1686 and 1696, exhibits the smallest number of floods of the series, affecting a smaller number of years. The fourth group, from 1785 to 1808 , recovered the number and duration of floods of the second group. The start of the second of these groups was gradual, from 1560, and the fourth group was observed to be prolonged up to 1814 , following a short interval with a small number of floods. The total number of years displaying an abundance of floods, $>0.5$ of the normal value, is $88 ; 44.3 \%$ of these are concentrated in the first group, $18.2 \%$ in the second group, $11.4 \%$ in the third group and $26.1 \%$ in the fourth group (Table 5). 


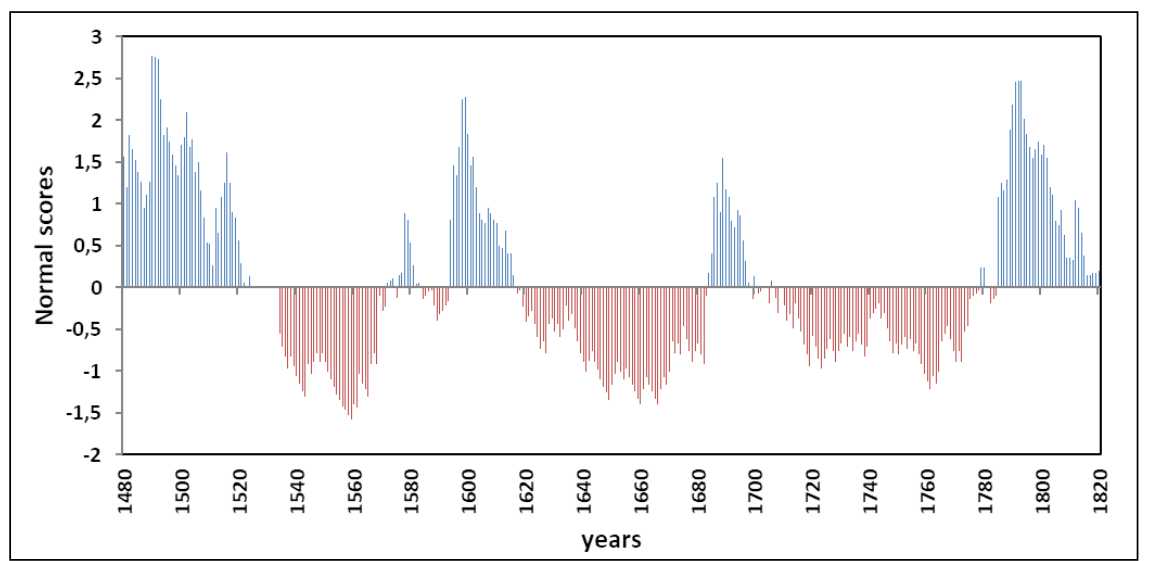

Figure 6. Cycle-tendency series of the abundance of floods in the Jarama valley. $<0.5$ and $>0.5$ from the normal value.

Table 5. Group of years with high and low abundance of floods.

\begin{tabular}{|c|c|c|}
\hline \multicolumn{3}{|c|}{ High floods $>\mathbf{0 . 5}$} \\
\hline Group of years & Cases & \% \\
\hline $1481-1520$ & 39 & 44.3 \\
\hline $1594-1610$ & 16 & 18.2 \\
\hline $1686-1696$ & 10 & 11.4 \\
\hline $1785-1808$ & 23 & 26.1 \\
\hline Total & 88 & \\
\hline
\end{tabular}

\begin{tabular}{|c|c|c|}
\hline \multicolumn{3}{|c|}{ Low floods $<-\mathbf{0 . 5}$} \\
\hline Group of years & Cases & \% \\
\hline $1534-1568$ & 34 & 25.2 \\
\hline $1638-1682$ & 44 & 32.6 \\
\hline $1716-1773$ & 57 & 42.2 \\
\hline & & \\
\hline & 135 & \\
\hline
\end{tabular}

In the series as a whole, the 135 years with low floods are also highly characteristic, scoring $<0.5$ points below the normal value; the most prolonged series, between 1716 and 1773, lasted 57 years, although the period between 1638 and 1682 is very long. Not only is the third group of floods $>0.5$ (1686-1696) the least abundant but it is also preceded and followed by years of few floods, ranging from the second half of the $17^{\text {th }}$ century to the 1770s. Regardless of this statistical grouping, individual floods could have caused severe damage on specific occasions in any of the years.

\section{Interpretation and discussion of results}

\subsection{Fluvial dynamics and changes in the floodplain}

The fluvial activity in the historical period analysed was not uniformly distributed; rather, it affected different segments. Actions to straighten the meanders during the Middle Ages were focused in segment 1. During the $15^{\text {th }}$ and $17^{\text {th }}$ centuries, the most affected sector was segment 2 , representing the most significant in terms of complexity and the volume of sediment moved. In most recent times, the silting and remodelling of the alluvial plain occurred in segment 3 . 
The old abandoned channel may have coexisted with the new channel for some time, as there is a document from the $15^{\text {th }}$ century that refers to the place separated by the two channels as being located "between the two bodies of water" (AVM 3-16912). There is also evidence that the old abandoned channel would occasionally fill with water when there were significant floods, flowing northward (RCHV R E, 1736, $33,1591)$.

Based on the position of the old river layouts and of the abandoned meanders, it is deduced that, between medieval and modern ages, the Jarama River has undergone a northward migration, moving next to the Páramo of Vaciamadrid. As the flow became established along this trajectory, there would likely be an increase in flow instability, water speed and capacity for sediment mobilisation.

The historical evolution on the alluvial flood plain appears to result from the fact that the river was shortened by the abandonment of the medieval channel, the consequence of which was a strong accumulation of sediments on the right-hand bank of the river in segment 2 and the remodelling of the alluvial plain in segment 3 (Fig. 3).

Since the end of the $15^{\text {th }}$ century, the Jarama River alluvial plain has been very unstable from a human point of view. Numerous dams and stockades were built to contain and guide the current, but the technology of the time was insufficient to mitigate the severest floods. Despite the potential danger of the river, the natural resources of the alluvial plain were highly valued, and exploiting the land was productive. Together with and perhaps conditioned by these changes in the river, several modifications in land use were historically transcendent. These modifications include the transformation of communal pastures into private and public property during the $15^{\text {th }}$ and $16^{\text {th }}$ centuries that occurred within the context of not having the funds necessary to repair the severe damages caused by the river floods. (LACM, Vol. $1,1489)$.

\subsection{Interpretation of the temporal sequence of floods}

The temporal classification of floods into the specific groups of years reveals that the high incidence of floods shows a pattern of repetition until the end of each of the centuries considered, albeit with different degrees of abundance and duration. The classification of years exhibiting a higher abundance of floods coincides with the research background referring to copious precipitation, whereas years with fewer floods tend to coincide with periods of drought.

The sequences established for the Late Holocene in the previous references coincide with our results because they indicate that the climatic conditions between the $11^{\text {th }}$ and $13^{\text {th }}$ centuries form a part of the Medieval Climate Anomaly (MCA), characterised by high temperatures and low precipitation (Dominguez- Castro et al., 2014), whereas the $14^{\text {th }}-18^{\text {th }}$ centuries, until the start of the $19^{\text {th }}$ century, appear to be integrated within the Little Ice Age (LIA), especially concentrated within certain groups of years. Different research projects (Corella et al., 2012; García-Ruiz et 
al., 2014; Barreiro-Lostres et al., 2017), based on the study of sediments in lakes in different parts of the Iberian Peninsula and on tree ring analysis, establish the relationship between high flood intensity and wet years, obtaining a time pattern that is compatible with the data presented herein.

Morellón et al. (2012) detect a transitional phase between the MCA and the LIA between the $14^{\text {th }}$ and $16^{\text {th }}$ centuries with fluctuating wet conditions and relatively low temperatures, particularly wet conditions between 1460 and 1550 , followed by the most intense phases of the LIA, corresponding, according to Steinhilber et al. (2009), to the minimums of solar radiation of Maunder (1645-1715) and Dalton (1790-1830). These phases coincide with the temporal concentration of the flood events detected herein and would appear to indicate the start of a new climate type (Fig. 6).

The chronology provided by Morellón et al. (2012) is compatible with the results obtained for the Jarama River in relation to the first group of floods, between 1481 and 1520, which appears to be a part of the transitional stage between the MCA and the LIA; this group also appears to coincide with the high precipitation detected in northern Morocco (Trouet et al., 2009; Till and Guiot, 1990) and Spain (Manrique and Fernández-Cancio, 2000; Ramos-Román et al., 2018) during these years. The group of floods between 1594 and 1610, which also appears to belong to the transitional stage of the LIA, coincides with the years of intense floods detected in different river basins in Spain (Llasat et al., 2005; Bullón, 2011; Oliva et al., 2018), and Europe (Brázdil et al., 1999; Glaser et al., 2010).

The following two groups appear to coincide with the most intense phases of the solar minimum of the LIA: the 1686-1696 group could be integrated within the Maunder Minimum and the 1785-1808 group in the Dalton Minimum. The former group has a relatively lower abundance of floods detected in the Jarama valley compared with those of the other three groups, which are concentrated in a smaller number of years. Despite the fact that this group appears to coincide with intense cold in the Iberian mountains (González-Trueba et al., 2008; García-Ruiz et al., 2014; Gómez-Ortiz et al., 2018), the smaller number of floods might also be consistent with the dry period between 1650 and 1715 (Domínguez-Castro et al., 2010; López-Blanco et al., 2016). There is a higher degree of coincidence between the Dalton Minimum and a period of abundant floods in the Jarama valley, which is in agreement with the abundant floods and precipitation in Andalucía (Rodrigo et al., 2008; Rodrigo, 2018), Cataluña (Maldá anomaly), (Barriendos and Llasat, 2003) and the Tagus River (Benito et al., 2003). This timing coincides with other similar studies reported in Europe (Brázdil et al., 1999; Glaser el al., 2010).

The wet weather during the LIA, which has been defined by abundant precipitation and floods, appears to have been caused by a higher frequency of negative phases of the North Atlantic Oscillation (NAO) (Luterbacher et al., 2010). These negative phases seem to occur mainly in winter, although according to recent contributions, they would exhibit a variable temporal intensity on being conditioned by other Atlantic meteorological models, such as the East Atlantic (EA) pattern (Bastos, 2016; Sánchez-López, 2016). 


\section{Conclusions}

The history of the occupation and management of the land on the Jarama alluvial plain can explain the detected evolution of the fluvial dynamics. The historical documents serve as chroniclers of the river dynamics, which in this case represent perfectly located and dated scientific data. The human and fluvial events are so closely interlinked that it is possible to establish a causal relationship linking the abandonment of a part of the medieval meandering channel, the increased fluvial activity in the river sections analysed and the change in the position of the confluence of the two main rivers, Jarama and Manzanares.

The dynamics of the river circulating across its alluvial plain have consisted of transforming the meandering channels into braided channels at different stages of its evolution and of the control and distribution of the sedimentary load.

The different phases of the LIA defined herein coincide with much of the palynological and dendrochronological research conducted in other areas of the southwestern fringe of Europe. The temporal sequence obtained from the classification of floods in relation to the LIA is of general significance beyond the study area because, despite the abundant floods that have occurred, the Jarama River retains as a reference the signal of the climatic-fluvial oscillations that occurred during the LIA, which have been referred to in many other places and river basins.

There is a relationship between changes in fluvial dynamics and the times of the greater abundance of floods. An initial change in the alluvial plain took place in the Middle Ages; this resulted from the abandonment of the medieval layout and the creation of a new channel parallel to the páramo of Vaciamadrid. The second change occurred between the $15^{\text {th }}$ and $17^{\text {th }}$ centuries and affected the properties on the righthand bank of the river. Since the $18^{\text {th }}$ century, the abandonment of and reduction in meanders, the southward channel migration in segment 2 and the aggradation at the Jarama-Manzanares confluence have created a new design of the alluvial plain of the river in segment three, with soil use devoted to agriculture.

The most noteworthy changes in the river and in the organisation of the land ownership occur in the transition between the medieval period and the modern age, coinciding with the initial phases of the LIA. The subsequent phases of this period coincide with an intense aggradation and with a change in land use from a seminatural landscape of pastures and forestland to one dominated by cereal croplands.

The correspondence among changes in the shape and dynamics of Jarama River main channel, land management and the different climatic phases is shown in Table 6. 
Table 6. Correspondence between fluvial evolution, land management and climatic phases in the Jarama River alluvial plain in different historical periods.

\begin{tabular}{|c|c|c|c|}
\hline Period & Fluvial dynamic and morphology & Land management & Climatic phase \\
\hline $\begin{array}{l}\text { Andalusí- Chris- } \\
\text { tian period } \\
8^{\text {th }} \text { to } 12^{\text {th }} \text { cen- } \\
\text { turies }\end{array}$ & $\begin{array}{l}\text { Meandering channel, running in a south- } \\
\text { west direction. Confluence with the } \\
\text { Manzanares } 4 \mathrm{~km} \text { southward from the } \\
\text { current mouth. }\end{array}$ & $\begin{array}{l}\text { Start of the occupation of the territory, } \\
\text { definition of land properties and of com- } \\
\text { munal pastures. }\end{array}$ & $\begin{array}{l}\text { Medieval Clímate } \\
\text { Anomaly (MCA) }\end{array}$ \\
\hline $\begin{array}{l}13^{\text {th }} \text { to first decade } \\
\text { of } 17^{\text {th }} \text { centuries }\end{array}$ & $\begin{array}{l}\text { Meandering cut-offs in segment } 1 \text {. Aban- } \\
\text { donment of a part of the meandering chan- } \\
\text { nel in segment } 2 \text { and formation of a new } \\
\text { one next to the escarps of Vaciamadrid. } \\
\text { The new channel has braided shape and has } \\
\text { intense erosion/ sedimentation. Confluence } \\
\text { Manzanares-Jarama close to Vaciamadrid. }\end{array}$ & $\begin{array}{l}\text { Maximum expansion of territorial occu- } \\
\text { pation without any substantial change in } \\
\text { land uses, with a slow evolution of the } \\
\text { communal pastures to municipal, royal or } \\
\text { church ownership. Land properties are re- } \\
\text { structured to adapt them to fluvial changes. }\end{array}$ & $\begin{array}{l}\text { Transition MCA- } \\
\text { Little Ice Age (LIA) } \\
\text { and } \\
16^{\text {th }}-17^{\text {th }} \text { LIA phase }\end{array}$ \\
\hline $\begin{array}{l}17^{\text {th }} \text { to } 18^{\text {th }} \\
\text { centuries }\end{array}$ & $\begin{array}{l}\text { Intense fluvial activity continues in seg- } \\
\text { ment } 2 \text {. Migration of the Manzanares } \\
\text { mouth towards the south. New meander- } \\
\text { ing cut-offs in segment } 1 \text {. }\end{array}$ & $\begin{array}{l}\text { Redefinition of land properties in seg- } \\
\text { ment } 3 \text {. Beginning of ploughing with } \\
\text { radical reduction in pastures and forest } \\
\text { land uses. The old and long-term lasting } \\
\text { landscape disappears. }\end{array}$ & $\begin{array}{l}\text { Maunder and Dal- } \\
\text { ton Minimum } \\
\text { LIA phases }\end{array}$ \\
\hline $19^{\text {th }} 20^{\text {th }}$ centuries & $\begin{array}{l}\text { Remodelling in the Manzanares-Jarama } \\
\text { alluvial plain. The river dynamics are } \\
\text { controlled by human action. }\end{array}$ & $\begin{array}{l}\text { Extensive ploughing of the alluvial plain, } \\
\text { desamortización of public and Church } \\
\text { ownerships, building of catchment reser- } \\
\text { voirs and extraction of sand and gravel in } \\
\text { the alluvial plain. }\end{array}$ & Current climate \\
\hline
\end{tabular}

In summary, the present research reveals the close relationship between human history and river history, in which climatic crises are drivers of fluvial self-regulation and the remodelling of the alluvial plain.

\section{Acknowledgements}

This research line is related to the projects "Heritage landscapes in South-Central Spain" (CSO2012-39564-C07-03) and Cultural Landscapes of the World Landscape list, (CSO2015-65787-C6-1-P) funded by the Dirección General de Investigación Científica y Técnica (Ministerio de Economía y Competitividad de España).

\section{References}

Alvar, A., García, E., Prieto, T., Zofío, J.C. 2005. Clima, técnica y poderes. Madrid 1561-1598. Revista de Historia Moderna 23, 135-184. http://digital.csic.es/bitstream/10261/14828/1/ RHM_23_06.pdf.

Arche, A. 2009. Coarse-grained meander lobe deposits in the Jarama River, Madrid, Spain. In: D.G. Collinson, J. Lewin (Eds.), Modern and ancient fluvial Systems. Willey on line library. https://doi.org/10.1002/9781444303773.ch25.

Arroyo Illera, F. 2002. Orígenes y antecedentes de la Real Acequia del Jarama. Estudios Geográficos 63 (248-249), 409-442. https://doi.org/10.3989/egeogr.2002.i248-249.233.

Barreiro-Lostres. F., Moreno, A., González-Sampériz, P., Giralt, S., Nadal-Romero, E., ValeroGarcés, B. 2017. Erosion in Mediterranean mountain landscapes during the last millennium: a quantitative approach based on lake sediment sequences (Iberian Range, Spain). Catena 149, 782-798. http://doi.org/10.1016/j.catena.2016.05.024.

Barriendos, M., Llasat, M.C. 2003. The case of "Maldá" anomaly in the western Mediterranean Basin (AD 1760-1800): An example of a strong climatic variability. Climatic Change 61, 191-216. https://doi.org/10.1023/A:1026327613698. 
Barriendos, M., Rodrigo, F. 2006. Study of historical flood events on Spanish rivers using documentary data. Hydrological Sciences Journal 51 (5), 765-783. https://doi.org/10.1623/ hysj.51.5.765.

Barriendos, M., Coeur, D. 2004. Flood data reconstruction in historical times from non instrumental sources in Spain and France. In: G. Benito, V.R. Thorndycraft (Eds.), Systematic palaeoflood and historical data for the improvement of flood risk estimation. Centro de Ciencias Medioambientales, Madrid, pp 29-42.

Bastos, A., Janssens, I.A., Gouveia, C.M., Trigo, R.M., Ciais, P. Chevalier, F., Peñuelas, J., Rödenberg, C., Piao, S., Friedlingstein, P., Running, S.W. 2016. European land CO2 sink influenced by NAO and East-Atlantic Pattern coupling. Nature Communications 7, 10315. https://doi.org/10.1038/ncomms10315.

Benito, G., Díez-Herrero, A., Fernández de Villalta, M. 2003. Magnitude and frequency of flooding in the Tagus Basin (Central Spain) over the last millennium. Climatic Change 58, 171-192. https://doi.org/10.1023/A:1023417102053.

Brázdil, R., Glaser. R., Pfister, C., Dobrovolný, P., Antoine, J., Barriendos, M., Camuffo, D., Deutsch, M., Enzi, S., Guidoboni, E., Kotyza, O., Sánchez Rodrigo, F. 1999. Flood events of selected European rivers in the sixteenth century. Climatic Change 43, 239-285. https://doi. org/10.1023/A:1005550401857.

Brázdil, R., Wheeler, D., Pfister, C. 2010. European climate of the past 500 years based on documentary and instrumental data. Climatic Change 101, 1-6. https://doi.org/10.1007/ s10584-010-9866x.

Brázdil, R., Kundzewicz, Z.W., Benito, G. 2006. Historical hydrology for studying flood risk in Europe. Hydrological Sciences Journal, 51, 739-764. https://doi.org/10.1623/hysj.51.5.739.

Bullón, T. 2011. Relationships between precipitation and floods in the fluvial basins of Central Spain based on documentary sources from the end of the $16^{\text {th }}$ century. Natural Hazards and Earth System Sciences 11 (8), 2215-2225. https://doi.org/10.5194/nhess-11-2215-2011.

Camuffo, D., Bertolin, C., Barriendos, M., Dominguez-Castro, F., Cocheo, C., Enzi, S., Sghedoni, M., Della Valle, A., Garnier, E., Alcoforado, M.J., Xoplaki, E., Luterbacher, J., Diodato, N., Nunes, M.F., Rodriguez, R. 2010. 500-year temperature reconstruction in the Mediterranean Basin by means of documentary data and instrumental observations. Climatic Change 101, 169-199. https://doi.org/10.1007/s10584-010-9815-8.

Corella, J P., Mangili, C., Vegas-Villarrubia, T., Morellón, M., Rull, V., Valero-Garcés, B., Brauer, A. 2012.The 1.5 ka varved records of Lake Montcortés (Southern Pyrenees, NE Spain). Quaternary Research 78, 323-332. http://dx.doi.org/10.1016/j.yqres.2012.06.0022012.

Dominguez-Castro, F., Garcia-Herrera, R., Ribera, P., Barriendos, M. 2010. A shift in the spatial pattern of Iberian droughts during the $17^{\text {th }}$ century. Climate of the Past 6, 553-563. https:// doi.org/10.5194/cp-6-553-2010.

Dominguez-Castro, F., De Miguel, J.C., Vaquero, J.M., García Herrera, R. 2014 . Climatic potential of Islamic chronicles in Iberia: Extreme droughts (AD 711-1010). The Holocene 24 (3), 370374. https://doi.org/10.1177/0959683613518591.

Fernández, M. 2004. La Tierra de Madrid en la época del Fuero de Madrid (Siglos XII-XIII). In: M. Montero Vallejo (Ed.), Jornadas sobre el Fuero de Madrid. Instituto de Estudios Madrileños, Madrid, pp. 187-215.

Fernández, F., Alloza A., Moreno, F. 2016. La presa del Vado y el Canal del Jarama. Madrid, Fundación Canal.

García-Ruiz, J.M., Palacios, D., De Andrés, N., Valero-Garcés, B., López-Moreno, J., Sanjuan, Y. 2014. Holocene and Little Ice Age glacial activity in the Marboré cirque, Monte Perdido massif, Central Spanish Pyrenees. The Holocene 24 (11), 1439-1452. https://doi. org/10.1177/0959683614544053. 
Glaser, R., Riemann, D., Schönbein, J., Brázdil, R., Camuffo D., Dobrovolny P., Avan, E., Enzi, S., Halichove, M., Koenig, S., Kotyza, O., Limanovka, D., Mackova, J., Sghedoni, M., Martin, B., Himmelbach, I. 2010. The variability of European floods since AD 1500. Climatic Change 101, 235-256. https://doi.org/10.1007/s10584-010-9816-7.

Gómez, A. 1970. Libros de Acuerdos del Concejo Madrileño, 1464-1600, Vol. 2, 1486-1492. Artes Gráficas Madrileñas, Madrid.

Gómez-Ortiz, A., Oliva, M., Salvador-Franch, F., Salvà-Catarineu, M., Plana-Castelví, J.A. 2018. El interés geográfico de los documentos históricos en la explicación científica del foco glaciar del Corral del Veleta (Sierra Nevada, España) durante la Pequeña Edad del Hielo. Cuadernos de Investigación Geográfica 44 (1), 267-292. http://doi.org/10.18172/cig.3402.

González-Trueba, J. J., Martin Moreno, R., Martínez de Pisón, E., Serrano, E. 2008. "Little Ice Age" glaciation and current glaciers in the Iberian Peninsula. The Holocene 18, 551-568. https://doi.org/10.1177/0959683608089209.

Hernando, F. 2003. El patrimonio municipal de Madrid en el siglo XIII. Unpublished PhD. Universidad Autónoma de Madrid, Departamento de Historia Moderna, Madrid.

Llasat, M.C., Barriendos, M., Barrera, A., Rigo, T. 2005. Floods in Catalonia (NE Spain) since the $14^{\text {th }}$ century. Climatological and meteorological aspects from historical documentary sources and old instrumental records. Journal of Hydrology 313 (1/2), 16-31. https://doi. org/10.1016/j.jhydrol.2005.02.004.

López-Blanco, C., Andrews, J., Dennis, P., Miracle, R., Vicent, E. 2016. Sedimentary response of lake El Tobar, Spain, to climate: lake level changes after the Maunder Minimum. Journal of Quaternary Science 31 (8), 905-918. https://doi.org/10.1002/jqs.2915.

Luterbacher, J., Koenig, S.J., Franke, J., van der Schrier, G., Zorita, E., Moberg, A., Jacobeit, J., Della-Marta, P.M., Küttel, M., Xoplaki, E., Wheeler, D., Retishauser, T., Stösel, M., Wanner, H., Brádzil, R., Dovrovolny, P., Camuffo, D., Bertolin, C., van Engelen, E., Gonzalez Rouco, F.J., Wilson, E., Pfister, C., Limanovka, D., Nordli, Ø., Leijonhufvud, L., Söderberg, J., Allan, R., Barriendos, M., Glaser, R., Riemann, D., Ha, Z., Zerefos, C.S. 2010. Circulation dynamics and its influence on European and Mediterranean January-April climate over the past half millennium: results and insights from instrumental data, documentary evidence and coupled climate models. Climate Change 101,201-234. https://doi.org/10.1007/s10584-0099782-0.

Madrazo, S., Bernardos, J., Hernando, F., de la Hoz, C. 1991. La Tierra de Madrid. In: S. Madrazo, V. Pinto (Eds.) Madrid en la época moderna: Espacio, Sociedad y Cultura, UAM Ediciones y Casa de Velázquez, Madrid, pp. 27-68.

Malalana, A., Martínez, S., Sáez, R. 1995. La ruta del Jarama y su entorno Andalusí. A.C. Almudayna, Madrid.

Manrique,E.,Fernández-Cancio, A.2000.Extremeclimatic events indendroclimaticreconstructions from Spain. Climatic Change 44, 123-138. https://doi.org/10.1023/A:1005458018568.

Martín Bañón, A. 2007. Espacios domésticos y de almacenaje en las confluencias de los ríos Jarama y Manzanares. In: Estudios sobre la Edad del Hierro en la Carpetania. Zona Arqueológica Vol II 20, pp. 27-41.

Millares, A, Artiles, J. 1932. Libros de Acuerdos del Concejo Madrileño, 1464-1600, Vol. 1, 14641485. Ayuntamiento de Madrid, Archivo de Villa, Madrid.

Molina, P., Berrocal, B. 2013. Dinámica fluvial, propiedad de la tierra y conservación del paisaje en el entorno de Aranjuez (Madrid, Toledo). Estudios Geográficos 74 (275), 495-522. https:// doi.org/10.3989/estgeogr.201318.

Morellón, M., Pérez-Sanz, A., Corella, J. P, Büntgen, U., Catalán, J., González-Sampériz, P., González-Trueba, J.J., López Sáez, J. A., Moreno, A., Pla-Rabes, S., Saz-Sánchez, M.A., Scussolini, P., Serrano. E., Steinilber, F., Stefanova, V., Vegas-Vilarrubia, T., Valero-Garcés, 
B. 2012. Multi-proxy perspective on millennium-long climate variability in the Southern Pyrenees. Climate of the Past 8, 683-700. http://doi.org/10.5194/cp-8-683.

Oliva, M., Ruiz-Fernández, J., Barriendos, M., Benito, G., Cuadrat, J.M., Dominguez-Castro, F., Garcia-Ruiz, J.M., Giralt, S., Gómez-Ortiz, A., Hernández, A., López-Costas, O., LópezMoreno, J.I., López-Sáez, J.A., Martínez-Cortizas , A., Moreno, A., Prohom, M., Saz, M.A., Serrano, E., Tejedor, E., Trigo, R., Valero-Garcés, B., Vicente-Serrano, S.M. 2018. The Little Ice Age in Iberian Mountains. Earth-Science Review 177, 175-208. https://doi.org/10.1016/j. earscirev.2017.11.010.

Ollero, A., Elso, J. 2006. The need for a "fluvial territory" or "room for the river". Living with floods by acceptance of their functions. In: C. Baker, P. van Eijk (Eds.), Sustainable flood management: obstacles, challenges and solutions. Interreg IIIC Network FLAPP pp. 59-63.

Panera, J., Torres, T., Pérez-González, A., Ortiz, J.E., Rubio-Jara, S., Uribelarrea del Val, D. 2011. Geocronología de la terraza compleja de Arganda en el valle del río Jarama (Madrid, España). Estudios Geológicos 67 (2), 495-504. http://doi.org/10.3989/egeol405550.204.

Pérez González, A., Gallardo-Millán, J.L., Uribelarrea del Val, D., Panera, J., Rubio-Jara, S. 2012. La inversión Matuyama-Brunhes en la secuencia de terrazas del río Jarama entre Velilla de San Antonio y Altos de Mejorada, al SE de Madrid (España). Estudios Geológicos 69 (1), 35-46. https://doi.org/10.3989/egeol.40862.173.

Ramos-Román, M.J., Jiménez-Moreno, G., Camuera, J., García-Alix, A., Anderson, R.S., Jiménez-Espejo, F.J., Carrión, J.S. 2018. Holocene climate aridification impact interrupted by millennial-and centennial-scale climate fluctuations from a new sedimentary record from Padul (Sierra Nevada, southern Iberian Peninsula). Climate of the Past 14, 117-137. https:// doi.org/10.5194/cp-14-117-2018.

Rodrigo, F.S. 2018. A review of the Little Ice Age in Andalusia (Southern Spain): results and research challenges. Cuadernos de Investigación Geográfica 44 (1), 245-265. http://doi. org/10.18172/cig.3316.

Rodrigo, F.S., Barriendos, M. 2008. Reconstruction of seasonal and annual rainfall variability in the Iberian Peninsula $\left(16^{\text {th }}-20^{\text {th }}\right.$ centuries $)$ from documentary data. Global Planetary Change 63 (2-3), 243-257. https://doi.org/10.1016/j.gloplacha.2007.09.004.

Rodrigo, F.S., Esteban-Parra, M.J., Pozo-Vázquez, D., Castro-Díez, Y. 2000. Rainfall variability in southern Spain on decadal to centennial time scales. International Journal of Climatology 20, 721-732. http://doi.org/10.1002/1097-0088(20000615)20:7<721::AIDJO C520>3.0.CO;2-Q.

Rubio, C. 1979. Libros de Acuerdos del Concejo Madrileño 1464-1600, Vol 3: 1493-1497. Ayuntamiento de Madrid, Archivo de la Villa, Madrid.

Rubio, C., Sánchez, R., Cayetano, C. 1982. Libros de Acuerdos del Concejo Madrileño, 14641600. Ayuntamiento de Madrid. Archivo de la Villa, Madrid.

Sánchez, G. 1963. El Fuero de Madrid y los derechos locales castellanos. In: El Fuero de Madrid, Ayuntamiento de Madrid. Archivo de la Villa, Madrid.

Sánchez-López, G., Hernández, A., Pla-Rabes, S., Trigo, R.M., Toro, M., Granados, I., Sáez, A.S., Masque, P., Pueyo, J.J., Rubio-Inglés, M.J., Giralt, S. 2016. Climate reconstruction for the last two millennia in central Iberia: the role of East Atlantic (EA), North Atlantic Oscillation (NAO) and their interplay over the Iberian Peninsula. Quaternary Science Reviews 149, 135 150. http://dx.doi.org/10.1016/j.quascirev.2016.07.021

Santonja, M., López, N., Pérez-González, A., Querol, A. 1979. Los sitios de ocupación del arenero de áridos S.A. (Arganda, Madrid). I Jornadas de estudios sobre la provincia de Madrid. Diputación Provincial, Madrid, pp. 44-53.

Santonja, M., López, N., Pérez González, A. 1980. Ocupaciones Achelenses en el valle del Jarama. Arganda (Madrid). Diputación Provincial de Madrid. 
Sánchez, G., Millares, C., Gómez Iglesias, A., Lapesa, R. 1982. El Fuero de Madrid y los derechos locales castellanos en el Fuero de Madrid. Ayuntamiento de Madrid. Archivo de la Villa, Madrid.

Silva, P., Goy, J.L., Zazo C. 1988. Neotectónica del sector centro-meridional de la Cuenca de Madrid. Estudios Geológicos 44, 415-427. https://doi.org/10.3989/egeol.88445-6558.

Silva, P. 2003. El Cuaternario del valle inferior del Manzanares (Cuenca de Madrid, España). Estudios Geológicos 59, 107-131. https://doi.org/10.3989/egeol.03591-488.

Steinhilber, F., Beer, J., Fröhlich, C. 2009. Total solar irradiance during the Holocene. Geophysical Research Letters 36, L19704. https://doi.org/10.1029/2009GL040142.

Till,C., Guiot,J. 1990. Reconstruction of precipitation in Morocco since 1100 A.D. based on Cedrus Atlantica tree-ring withs. Quaternary Research 33, 337-351. https://doi.org/10.1016/00335894(90)90060-X.

Trouet, V., Esper, J., Grahan, N.E., Baker, A., Scourse, J.D., Frank, D.C. 2009. Persistent positive Atlantic oscillation mode dominated by the Medieval Climate Anomaly. Science, 324 (5923), 78-80. https://doi.org/10.1126/science.1166349.

Uribalarrea, D., Pérez González, A., Benito, G. 2003. Channel changes in the Jarama and Tagus rivers (central Spain) over the past 500 years. Quaternary Science Reviews 22, 2209-2221. https://doi.org/10.1016/S0277-3791(03)00153-7.

Uribelarrea, D., Díez Herrero, A., Benito, G. 2004. Actividad antrópica, crecidas y dinámica fluvial en el sistema Jarama-Tajo. Itinerarios geomorfológicos por Castilla-La Mancha. (Excursiones de la VIII Reunión Nacional de Geomorfología, Toledo, 22-25 de septiembre de 2004), CSIC y SEG, Madrid.

Vizcaíno, P., Magdaleno, F., Seves, A., Merino, M., González Tánago, M., García de Jalón. D. 2003. Los cambios geomorfológicos del rio Jarama como base para su restauración. Limnetica 22 (3-4), 1-8. http://www.limnetica.net/Limnetica/Limne22/L22b001_Cambios_ geomorfologicos_rio_Jarama.pdf.

Wolf, D., Seim, A., Díaz del Olmo, F., Faust, D. 2013. Late Quaternary fluvial dynamics of the Jarama River in central Spain. Quaternary International 302, 20-41. https://doi.org/10.1016/j. quaint.2013.02.012.

Wolf, D., Faust, D. 2016. River braiding caused by rapid floodplain deformation. Insights from Holocene dynamics of the Jarama River in Central Spain. Quaternary International 407, 126-139. https://doi.org/10.1016/j.quaint.2016.01.027. 